\title{
Ata de criação da Revista Educação em Questão
}

A Revista Educação em Questão foi criada em 18 de abril de 1986. Nesta edição, o Conselho Editorial da Revista Educação em Questão, para homenagear os Trinta Anos dessa Revista, publica a Ata da Reunião Plenária Extraordinária dos Professores do Departamento de Educação (dia 18 de abril de 1986) da Universidade Federal do Rio Grande do Norte que aprovou a sua institucionalização.

\section{Reunião Plenária Extraordinária [Departamento de Educação] do dia 18 de abril de 1986}

Aos 18 dias do mês de abril do ano de mil novecentos e oitenta e seis, reuniram-se os professores do Departamento de Educação para deliberar sobre o projeto da Revista de Educação. Inicialmente, o professor José de Castro colocou em pauta, as propostas a serem analisadas: 1. definir o público destinatário da Revista; 2. definir seus objetivos; 3. definir formato; tema central para $\circ 1^{\circ}$ número; ou não tema central; 4 . filosofia e linhas mestras; 5. nome e periodicidade; 6 . Conselho Editorial - mandato, composição, atribuições, forma e funcionamento. Em seguida a professora Ana Lourdes Menezes Magalhães fez uma explanação de como se encontra o projeto. Comunicou que já existia uma Revista elaborada. Então foi indagado ao plenário se a Revista seria editada como se encontra ou se seria discutido os propostas apresentadas. Houve uma votação e o plenário decidiu que fossem discutidas às propostas. Inicialmente foi discutido a que público à Revista se destina. Após várias sugestões apresentadas ficou decidido que seria destinada a toda comunidade educacional. Prosseguindo a sessão o plenário definiu os objetivos da Revista: divulgar trabalhos e experiências pedagógicas dos docentes e discentes; estimular a produção científica de professores e alunos (Graduação e Pós-Graduação); divulgar noticiário do Departamento de Educação e da 
vida acadêmica da UFRN e eventos educacionais científicos e culturais. Como objetivo geral, estimular a produção, divulgação e ampliação da discussão científica sobre educação respaldadas nos fatos políticos, econômicos e sociais relevantes no contexto nacional. Prosseguindo a sessão, passou a ser discutido se a Revista vai sair com tema central. Após as discussões ficou decidido que o Conselho Editorial ficará responsável pela publicação dos artigos, a partir das matérias recebidas e enviada a comunidade de professores e alunos e dependendo do momento caso algum tema polarizador justifique a solicitação de artigos para o número da Revista. Dando continuidade a sessão, passou a ser debatido a filosofia e linhas mestras da Revista. Inicialmente, foram apresentadas duas propostas: $1^{\circ}$ que seja aberta à participação de todos e que os artigos publicados reflitam: a) o pensamento hegemônico do Departamento de Educação; b) o momento político da Revista; c) a preocupação com a qualidade; d) o respeito ao pensamento divergente. $2^{\circ}$ que seja aberta à participação de todos, respeitando-se as diversas correntes de pensamento e atendendo a critérios de qualidade estabelecidos pelo Conselho Editorial. As duas propostas foram votadas, sendo que a $2^{\circ}$ proposta com 17 votos a favor e três abstenção. Continuando a sessão passou a ser discutido a composição do Conselho Editorial. O professor José de Castro usou da palavra e comunicou que inicialmente a Comissão foi formada por três professores: José Pires, Gerusa Sotero da Cunha e Maria Estela Costa Holanda Campelo. Depois ele e a professora Maria Júlia de Paiva Almeida foram convidados pelo grupo para se integrarem a Comissão. Na oportunidade o professor indagou ao plenário se a comissão permanecia e se a necessário sua ampliação. Finalmente o Conselho ficou constituído por sete professores, 2 estudantes, um de graduação e um de pós-graduação, mais os consultores. Ficou decidido que os dois professores acrescentados sejam escolhidos na próxima plenária. Antes de encerrar a sessão a professora Ana Lourdes agradeceu a presença de todos e não havendo mais nada a tratar eu Damiana André da Silva lavrei a presente ata que depois de lida e aprovada será assinada por mim e pelos presentes. Natal, 18 de abril de mil novecentos e oitenta e seis.

Damiana André da Silva

Maria Aparecida de Queiroz

Francisco de Assis Pereira 
Lúcia Caldas Gomes

Nancy Gomes dos Santos

Neide Varela Santiago

Maria Júlia de Paiva Almeida

José de Castro

Ana Lourdes Menezes Magalhães

Luzia Diva Cunha Dutra

Antonio Cabral Neto

Eunice Ariston

Hilda Câmara Martins de Vasconcelos

Maria Joana D'arc Silveira de Medeiros

lolanda Brito Guimarães

Maria do Perpétuo Socorro de Menezes

Gerusa Sotero da Cunha

Maria da Paz Gomes Chagas

264 Eleika Bezerra Guimarães 